\title{
ENHANCING LEARNING INTEREST OF EIGHTH GRADERS AT SMP N 1 ABUNG SELATAN BY THE APPLICATION OF COOPERATIVE LEARNING METHOD AND MEDIA
}

\author{
Rini Susilowati ${ }^{1}$ \\ rini.ariyanto12@gmail.com
}

\section{Universitas Muhammadiyah Kotabumi}

\begin{abstract}
Direktorat pembelajaran always makes effort to improve education quality in Indonesia through revitalization program of Lembaga Pendidikan Tenaga Kependidikan (LPTK). One of the programs is Penugasan Dosen di Sekolah (PDS). PDS is a program which aimed to build partnership between LPTK and lab schools as well as the other partner schools. The main goal is to improve the quality of teacher candidate and professional teacher. Relating to that goal, LPTK lecturer has a duty to teach directly at partner school and collaborate with partner teacher in the attempt to prepare and conduct an interesting, effective and technological based learning in order it can engage students' learning interest. Therefore, cooperative learning method and media in this PDS program are applied in the attempt to increase students' learning interest in English class.
\end{abstract}

Keywords : interest, cooperative learning, media, PDS

Abstrak: Direktorat Pembelajaran senantiasa berupaya untuk meningkatkan kualitas Pendidikan di Indonesia melalui program revitalisasi Lembaga PendidikanTenaga Kependidikan (LPTK). Salah satu program revitalisasi tersebut adalah program Penugasan Dosen di Sekolah (PDS). PDS adalah program yang ditujukan untuk menjalin kemitraan antara LPTK dengan sekolah laboratorium dan juga sekolah mitra lainnya. Tujuan utamanya adalah untuk meningkatkan kualitas calon guru dan guru professional. Terkait tujuan tersebut, dosen LPTK sebagai muara dari pendidik calon guru ditugaskan dalam program PDS ini dengan cara mengajar langsung di sekolah mitra dan berkolaborasi dengan guru mitra dalam upaya untuk mempersiapkan dan melakukan suatu pembelajaran yang menarik, efektif, dan berbasis teknologi sehingga dapat lebih menarik minat belajar siswa. Oleh karena itu dalam program PDS ini dilakukan penerapan metode Cooperative Learning dan penggunaan media dalam upaya meningkatkan minat belajar siswa di kelas Bahasa Inggris.

Kata kunci : minat, pembelajaran kooperatif , media, PDS

\section{INTRODUCTION}

The learning quality from Lembaga Pendidikan Tenaga Kependidikan (LPTK) always been improved through some revitalization programs. One of the program was conducted in 2016 through curriculum development for the study program based on
Kerangka Kualifikasi Nasional Indonesia (KKNI). The product of the program was curriculum and Rencana Pembelajaran Semester (RPS). Meanwhile, as the continuation of the program in 2016, Direktorat Pembelajaran had the other revitalization program in the attempt to 
develop the learning tools based on the developing curriculum from the previous revitalization program in 2017. In addition, Direktorat Pembelajaran made such the same program again in 2018 in the form LPTK revitalization donation which concerned to the partnership between LPTK and lab school or between LPTK and partner school to improve the quality of teacher candidate as well as professional teacher. This revitalization donation program called as Deployment program or Program Penugasan Dosen di Sekolah $(P D S)$.

The aims of PDS generally concern to improve the quality of human resource. The qualified human resource can be produced only from qualified education with qualified teachers, and the qualified teachers can be produced only from qualified LPTK. Relating to qualified teachers, the main source of teacher education is lecturer. Instead of having qualified competence, LPTK lecturer should be good role model for the teacher candidate and also giving such good model of how to conduct the learning in the class. In order that LPTK lecturer can give the real description of how to conduct a good learning in the class which relevant to the newest quality needed at school, so LPTK lecturer should experience directly of how teaching at the school through Deployment program or PDS.
PDS program requires lecturer to have high commitment in conducting this program because learning situation at school is really different from the place where the lecturer teaches. Adapting to the new place where there are different students with different characteristics should be done. Discussions related to how to arrange the learning schedule including, the material learnt in the class, the teaching method, the activities prepared, and the media used should be made between the lecturer and the partner teacher at school where PDS will be conducted. The goal of this preparation is to know and to analyze the students' need in the class and determining the appropriate and effective teaching method to create such an enjoyable and interesting teaching and learning process for the students.

Relating to the previous explanation, the goal of PDS is also as the collaborative partnership between the lecturer and the partner teacher to form some learning tools in which it can be implemented collaboratively by the lecturer and the teacher directly in the class. From the implementation it can be resulted more effective and qualified teaching learning process with various learning model or strategy, more qualified learning tools which can be applicated further after PDS has been finished, the improvement of students' progress, and stronger partnership between LPTK lecturer and lab school teacher or 
between LPTK lecturer and partner school teacher.

In this case, this article giving more vivid description of how a lecturer had a partnership with an English teacher of SMP N 1 Abung Selatan, Kotabumi North Lampung. The lecturer who has conducted this program was from Universitas Muhammadiyah Kotabumi, North Lampung who teaches at English Education Study Program. Meanwhile, the teacher teaches some English classes at SMP N 1 Abung Selatan. This school is one of schools which has a lot of students. Each grade consist of more or less nine classes. The class which became the model for this PDS was class VIII G. There are 32 students with the equal amount of male and female students. Because the class can be categorized as large class based on the number of the students in it, so the lecturer and the teacher have made some discussions to prepare for their teaching plan so that the teaching and learning could run smoothly and the classroom could be managed well. Considering that applying some learning models and strategies is really important to support the success of PDS program, at the beginning of this program the lecturer as well as the teachers have done sharing sessions to discuss this matter. Meanwhile, learning media used also became the main concern in this program because the use of media could attract students' interest, having more focus to the material, making the learning more enjoyable and avoid students' boredom in the class. Based on the elaboration in the previous part, this article will describe vividly how PDS program conducted at SMP $1 \mathrm{~N}$ Abung Selatan as well as depicting how the application of some learning models and strategies of cooperative learning and also media can enhance students' learning interest in English class of SMP N 1 Abung Selatan Kotabumi North Lampung. Therefore, the next part of this article will describe the learning process from the eighth meetings that have been conducted in this PDS program.

\section{DISCUSSION}

\section{The Significance of Learning Interest}

Interest is willingness which triggers someone to do certain thing, an activity, or having certain goal in his or her life. Interest stimulates someone to do an effort in achieving the things he or she targeted in the life. Meanwhile, interest in learning relates to students' willingness in pursuing the learning potential in their study. Interest can influence many aspects. Motivation and achievement affected by the interest. If students having less interest on their mind, possibly their motivation getting lower too. In the opposite, the more interest the students possess in learning, the better and higher motivation they obtain. Therefore, interest closely related to motivation and 
those two things will affect learning achievement too. Interest is one of the strongest motivation for learning English, and motivation has been identified as one of the main factors affecting English language learning (Gardner, 1985) in Kusmaryati \& Amertaningrum (2017:185). Therefore, interest is something that teachers should really concern to.

Interest should be one of the important things that should be managed well by the teachers because it is the key point which determine students' success. Interest in learning motivates the students to gain new knowledge and always having willingness to enrich their potential by remembering, knowing, understanding, evaluating, and analyzing all things they learn. In addition, English learning interest motivates the students to gain good knowledge of language components and mastering the four skills in English. Because of that reason, in the attempt to stimulate students' interest, an enjoyable and conducive learning atmosphere should be created. Learning difficulty and anxiety should be managed well by the teachers so that students will not be distracted by those learning obstacles. Katz et.al. (2006) in Kusmaryati \& Amertaningrum (2017:186) state that interest is the enjoyment students feel when doing the task. In conclusion, interest will appear if students enjoy something they learn and do. When they can enjoy it, their motivation will arise too. As a result, when both interest and motivation work well together in the time when students doing their learning process, the learning outcome will be achieved better.

\section{The Significance of Cooperative Learning}

Teaching conventionally where teachers talk most of the time while students are busy making their notes whether they comprehend their teachers' explanation or not, students found talking in many classes of their subject, or lazy students who reluctant to read and to study who just sitting and sometimes sleeping in the class are some problems that should be overcomed. Teacher-centered is not relevant anymore to the principle of high order thinking skill (HOTS) learning. Students should be more critical to elaborate their mind to understand, to evaluate, and to analyze what they learn comprehensively. Furthermore, talking in the class can distract the classroom focus and the lazy students should not be ignored so that they will not be left behind the other students. Therefore, an appropriate method should be applied in the classroom to change that situation. Cooperative learning method is one of effective and interesting methods which has positive benefit for the learning to be fun and more enjoyable. Cooperative learning has been proved to be an effective teaching strategy to both the teacher and learner. It 
encourages learning to take place and allow communication skills to foster among learners (Jacobs \& McCafferty, 2006) in alYaseen (2014:92).

Cooperative learning method is the method which has various learning models, strategies and techniques in it. This method aims at developing students' qcooperation in learning in which they learn together to have the same idea and understanding of material learnt, helping each other to solve learning problems arise during the learning, sharping their confidence and independence. Johnson et al. (2000) in Almuslimi (2016:43) states, "cooperative learning is the instructional use of small groups so that students work together to maximize their own and each other's learning “. Cooperative learning method distribute the students into some heterogenous groups so that each group will have more or less the same learning progress. According to Bolukbas \& et. Al (2011) in Almuslimi (2016: 43) cooperative learning as a process through which students with various abilities, gender, nationalities and different levels of social skills carry out their learning process by working in small groups and helping each other.

The strength of this method is at its various activities done within the group, various steps and unique procedures conducted within the group discussion, various group task distribution, various point determination within the group's progress and achievement and the other interesting things. According to Macpherson (2007) in Almuslimi (2016:44) cooperative learning include a lot of things as: group task, positive independence, interpersonal cooperative skill building, participations, learners and teachers. This method is one of interesting methods which can be applied in teaching English as foreign and second language. It provides a non-threatening learning environment which encourages EFL learners to overcome their apprehension in communicating and expressing their point of view in a foreign language (Slavin:1995) in Al-Yaseen (2014:92). Because teaching the four skills in English is not easy and instant, teachers and educators need to apply interesting method. In this case, cooperative learning method with its variety can be one of effective solution in solving the students' problems in the class. Some cooperative learning method used in this program were demonstration, TAI, learning together, TGT, and group discussion.

\section{The Significance of Media}

Teaching requires not only good instruction, effective method, interesting activities, but also some equipment to support teaching to be more enjoyable, fun and modern. Technology helps everyone to have efficiency in time consumption. For example, someone can communicate easily and directly to someone else abroad through 
the use of technology such as web cam and skype. Meanwhile, teaching will not spend much time in the case that the teacher uses a kind of technology such as laptop to deliver the material. Instead of talking all the time which sometimes makes the students bored, the teacher can present the summary of the material through power point, giving explanation using some interesting pictures from the laptop to help the students connecting the content delivered in the pictures with the material learnt. The laptop considered as one of media that can be used in the classroom. Pun (2013) in Thaseem \& Kareema (2017:435) state that rapid development of technology and science such as multimedia refers to computer-based interactive teaching, requires people to deliver information and knowledge.

Laptop also a media that can be a tool to play audio-visual video. Usually the laptop is completed by Head projector to play the audio-visual video. Specifically, the audio from the audio-visual video can be transferred using a speaker. Those media can really support learning process, such as English language learning since learning English should be supported by a lot of exposure from the sound and the voice of native speakers' talk, some instructions of pronouncing English sounds and a lot of English dialogues. Besides, audio-visual media can also give beneficial support for English students to learn grammar, vocabulary, and also the four skills in English. Based on the result of a study, Gilakjani (2012) in Thaseem \& Kareema (2017:435) found that it is easy for English instructors to integrate audio-visual media in their instruction and the students get better learning. Furthermore, Kausar (2013) in Thaseem \& Kareema (2017:435) from his study state that audio-visual media has importance in English learning and the students having problems in English learning so that it is difficult to learn without the use of audio-visual media. In short, media is very useful aids to create enjoyable learning atmosphere and it really helps the students to diminish their learning difficulty.

The other findings obtained from other research proved that media is really significant in English class. Yunus, Salehi \& Johnson (2013) in Thaseem \& Kareema (2017:436) emphasized about teachers' view that the use of visual aids or media becomes motivational tool to enhance students' interest in learning English. In addition, Daniel (2013) in Thaseem \& Kareema (2017:436) state that audio-visual aids or media can enhance students' interest, saving time, and diminish teachers' burden, and creating different learning experience for the students.

In conclusion, based on the elaboration of the benefit of media and some findings obtained by researchers it may be said that the use of media is highly 
recommended in the classroom. Learning English as foreign language (EFL) will be easier to do because the students supported by some illustration from the pictures, the video, and other audio-visual media they use in the class.

\section{The Application of Cooperative Learning Method and Media to Enhance Eighth Graders' Learning Interest in English Class of SMP N 1 Abung Selatan}

The collaborative teaching hold in English subject of VIII G class. There were eighth meetings and it took for one and a half month started from the end of July 2019 until mid of September 2019. English class held twice in a week and the collaborative teaching sometimes held on Monday and Thursday. The time allotment for one meeting is 80 minutes. Therefore, there should be an exact time limitation for each activity during pre-activity, whilst-activity and post-activity. Meanwhile, there are some cooperative learning strategy and model applied during the collaborative teaching.

The first meeting was on Monday, July 29, 2019. The material given was modal "can" and "will". The students were divided into some groups but cooperative learning method has not been applied at this occasion with the consideration that the lecturer and the teacher would like to evaluate and analyze the students' characteristics and ability as well as their behavior in the class. Nevertheless, the group discussion kept running. Demonstration technique was used in this meeting. The students were asked to choose one of the rolled papers and on the paper some activities described by some phrases which was written. After that, one student demonstrated the activity using movement and gesture so that the other students can guess what activity represented by the demonstration. The students who were sitting on their seat were asked to demonstrate the activity by making the expression to show that someone can do something. The expression should use modal "can" in it. The same activity was done when modal "will" discussed in this meeting.

After brainstormed the students using demonstration technique, they were divided into some groups. Their task was identifying the example of expression to show that someone can do something using modal "can". Based on the evaluation of group discussion, it was found that many students still have difficulty in understanding the meaning of daily used words. It took time for them to look for the meaning on their dictionary. As a result, they needed much time to finish their task. Meanwhile, there were still inactive students who were not being involved in the discussion. Nevertheless, some students showed their courage to share their opinion and answer. 
Finally, the main-activity took more time as what have been planned before.

Referring to this condition, the lecturer and partner teacher made such evaluation and preparation of what should be done in the next meeting. In order to make learning to be more interesting, cooperative learning method was chosen. The method of cooperative learning applied was Team Accelerated Instruction (TAI). The lecturer as well as the partner teacher decided to choose this method because this method encourage all groups in the class to have their own obligation in finishing certain task given. Distributing equal number of questions that should be finished was hoped to challenge all groups to accomplish their task. Besides, time efficiency was also the other consideration because this method giving equal questions for each group to do and all group members should try to answer all questions given to their groups. Because of that reason this method will be used in the second meeting.

The second meeting was on Monday, August 5, 2019. The material learnt in this meeting was modal "should" which is using modal "should" to give suggestion to someone. In brainstorming time, some students seemed having courage to answer some questions given. They knew the meaning of modal "should" and how it was used. In the next activity, the lecturer gave more examples of expression using modal "should" to make clearer understanding. In whilst-activity, the students were divided into some groups. Meanwhile, the method used was Team Accelerated Instruction (TAI).

TAI was chosen because in the previous meeting it seemed that some groups still have difficulty in finishing their task. TAI is a method in which each group and each member in every group having responsibility to finish all task belong to them. In the process of doing the task, all members should help and support each other. According to Huda (2011:125) in Istikhayatun (2015:13) individual accountability, equal opportunities for success, and motivational dynamics become the main elements to be emphasized by the teacher. TAI helping the students to have sense of independence although they work together. The independence reflected through their duty to do the individual task which actually belong to group's task, but they should try to finish it individually by having discussion with other group members whenever they have difficulty. Therefore, supporting each other is also the main concern of this method.

Referring to the explanation before, the students of class VIII G where the collaborative teaching took place seemed not having quite good cooperation. Although the task has been distributed to all group members, there were still some 
groups which could hardly finish the task because they did not have quite good cooperation among group members. Some students were still unmotivated to do the task, and only the active and diligent students who really tried to finish the task. Besides, some students in some groups did the task slowly. As a result, not all groups were ready to share their answer in sharing session. In this case, some solutions have been found to avoid the same condition to be happened again in the next meeting. The lecturer and the teacher thought that giving the strict control related to time allotment in doing the task is really important. Therefore, the lecturer and the teacher will remind all groups to finish their task on time by maximizing the time for doing the things needed and avoiding to talk out of the material context. Furthermore, the lecturer and the teacher have decided to change the method used and used the media in the third meeting in order to attract students' interest in learning and the learning atmosphere will not be monotonous.

The third meeting was on Monday 26, August 2019. The material learnt was about the expression to invite someone to do something and the expression to give instruction. Considering that the ideal condition in the previous meeting has not been achieved, the new model used in this meeting was learning together. This model was not too complicated to be applied because it does not have difficult procedure. Johnson \& Jonhson (1998:226) in Ghaits (2003:453) say, "this model is less discrete and less prescriptive than the structural and the Student Team Learning Models that employ specific steps in lesson planning. During this meeting, the students divided into eighth groups consist of 4 students. Good cooperation is emphasized through each individual hard work which supporting each other to achieve group's success. Any difficulty should be solved together. Meanwhile, time allotment in doing the task is strictly announced and reminded at the beginning of discussion. Group's focus and good communication among group members helped discussion ran well.

Meanwhile, some media used in this meeting to make the learning to be more interesting. Pun (2013) in Thaseem \& kareema (2017:435) states, "this usage of multimedia technology has created a favorable condition in improving the interest in English language learning. Furthermore, using multimedia audio-visual aids stimulates thinking and improves learning environment in a classroom (Mathew \& Alidmat, 2013) in Thaseem \& Kareema (2017:435). Considering that there were some students who seemed not motivated to learn and to be involved in discussion in the second meeting, LCD projector, laptop, and a speaker were used in this occasion. Media can make the class atmosphere more alive 
because the students feel interest and more active in attending the class (Finocchiaro, 1973) in Syandri (2015:47). Besides, delivering the material through media made the students not feeling boredom and they were happy to see the video played through the laptop. In addition, the audio visual sent by the video made the students enjoy the learning because they felt relax. As stated by Suleiman (1985) in Syandri (2015:47) audio-visual aids (media) do not only give effective way of learning in shorter time, but also help to retain the information better and longer. As a result, they understood the material easily

The material delivered through some video contain some short dialogues with the expression of asking someone to do something and giving instruction. The students were really interested to watch the video and they tried to connect the content of the video with the material on their book. They could identify some expressions of inviting someone to do something and giving instruction from the video individually. Meanwhile, when they worked in group to find the other examples of the expression from the other video, they could do it well too. Moreover, a song which played in certain time of whilst-activity made them felt curious to hear the words and recognized the expression of asking someone to do something and giving instruction. Song can also become one of interesting media for junior high school students to learn English. Schoepp (2001) as cited from Sevik (2012) in Ranggen (2016:9) believes that songs are valuable in the classroom "to make an enjoyable activity that is able to contribute to a supportive, nonthreatening setting with confident and active learners". Therefore, song can be one of effective technique in delivering material in more fun way.

Based on the result of learning in this meeting it was found that using audio-visual media could attract students' willingness and motivation to be more engaged in learning activity. Understanding the material through not only teacher's explanation but also other kind of verbal thing in form of colorful and interesting video resulted more enjoyable situation. Nevertheless, a solid group cooperation still needs to be improved. Therefore, learning together model as well as the audio-visual media would be applied in the fourth meeting.

The fourth meeting was on Monday $2^{\text {nd }}$, September 2019. The material learnt in this meeting was expression for asking permission using modal "may" and "can". Learning together model was still used and audio-visual media considered as the effective visual aids which was successful to engage students' learning interest and motivation. At the pre-activity a song played to brainstorm the students' knowledge of the material. Based on some questions given to 
the students, they knew that there was one modal used in the song to explain the expression of asking permission. Some of the students also could identify some expressions of asking permission from the song. It proved that using song again in this meeting could motivated them to be more focused on the material delivered because they learnt in nice situation. According to Jolly (1975:14) \& Shin (2006) in Dzanic \& Pejic (2016:42) songs are useful teaching aids which raise and maintain students' motivation, especially in cases when they are catchy and supported with colorful visuals, realia, and movement.

After listening to a song and identifying some expressions to ask permission, the students worked in group. Learning together model still applied in discussion session. In this meeting they were asked to watch and listened the video and also identified some examples of expression in asking permission. Group cooperation improved well and each group member seemed to be involved in learning and discussion. After they watched the video, they made their own examples of expression in asking permission. When whole class hold to discuss each group's example of the expression, all group could answer well. Nevertheless, some groups still asked the same group representative to explain their answer. Therefore, the evaluation of this case should be made in order all students could achieve their progress.

Relating to the result of learning in the fourth meeting, the quality of group discussion should be maintained and some students who still be shame to talk in the class should be engaged to be active using other technique. Meanwhile, learning together model still be used in the fifth meeting.

The fifth meeting was on Thursday, September the fifth 2019. The expression learnt was getting attention or asking attention. Learning together model used in this meeting. This model still be applied because we noticed that the students were comfortable learning using this model. The lecturer's role and the teachers' role were guided them to work and to support each other so that all group members always make improvement in each meeting. A video played to brainstorm students' understanding toward the material in preactivity. It seemed the students have difficulty in catching the material. In order to make the learning more conducive, some students were asked to come in front of the class to read some examples of expression to get attention. They were quite confident to read the examples although some mistakes in pronouncing the sentence appeared. The good thing was they have been dare to receive the challenge. Meanwhile, other students sitting on the seat 
listened to what the student in front of the class said and they should repeat the sentence. After that, they identified which phrases were the expression of getting attention.

Group discussion held in whilst activity and each group identified some expressions of getting attention from the video. The use of video in this meeting really beneficial to keep students' focus because there was noise outside the class. In whole class session, all groups could recognize the examples of expression in asking attention from the video and they could mention the response from it too. The material in this meeting was quite difficult, so it took time to engage students' knowledge to catch the material. Nevertheless, the overall understanding have been achieved by all groups.

The good thing obtained from this meeting was students have practiced their listening which was integrated during the time they learnt the lesson. Although it was not too easy for them to listen to native speakers' talk in the video, they could recognize some expressions related to asking or getting attention from others. The thing that should be noticed was maintaining group cooperation by motivating all group members to be actively involved in group discussion all the time so that there were not only active students who share their opinion in whole class discussion. Therefore, combining learning together model with certain technique and strategy will be helpful to overcome this problem in the next meeting.

The sixth meeting was on Monday, September 9, 2019. The material learnt was expression to give appreciation and compliment. The model used was learning together because it considered effective and not too complicated to be implemented. At pre-activity, the students brainstormed through seeing one of their friends in the class and her clothes. They were asked to notice the way she dressed, whether she dressed neatly or not. After they notice one of their friends, they were asked to give compliment to her because she dressed neatly. The lecturer asked them the common "word" used to give appreciation and compliment. At the beginning they were confused, but after some concrete examples given to them, they knew that an adjective should be used to give appreciation and compliment. Because the students have already had understanding about the concept of "adjective", a video was played at the beginning of whilst activity. They listened to some examples of expression to give appreciation and compliment.

In listening and analyzing the video, the students were aware of some adjectives used to show compliment and appreciation. They could recognize some examples of expression from the video. Audio- visual 
media used really helped them to connect thing they learnt in the video to the material explained on their book. Besides, they enjoyed some utterances and short dialogues talked by the speakers in the video. In the next activity of whilst activity, they discussed the task with their groups. Group work seemed to be solid because they helped each other to do the task. Time allotment in doing the task was strictly controlled so that the students did not waste the time to talk and to make noise. After they finished to do the task, sharing session hold to know how well each group did the task. Many students were motivated to come in front of the class and wrote the result of their discussion. It was found that they were able to identify the correct expression of giving appreciation and compliment. They could also make the correct expression of giving appreciation and compliment of their own.

The thing noticed from this meeting was each group have maintained their cooperation well. They realized that helping each other will help them learn better and have more knowledge and understanding related to the material. Nevertheless, there was no doubt that there were still some students who have not tried to speak in whole class discussion. As a result, the lecturer and the teacher planned to used role play in the seventh meeting. Role play is the technique in which students make such kind of simple dialogue where they pretend to be someone else. They make scenario to make the dialogue to be alive. They plan the sentences as well as how they will behave using gesture in the role play. Ment (1983) in Krebt (2017:864) state that role play is an act of making certain behavior and appearance to refer to certain people of any kind personality. The goal of using role play was to stimulate the students who reluctant to speak to be dare expressing their mind and thought. Since English requires students to have a lot of practices in the four skills, so role play hoped can be good technique to improve students' speaking confidence and the ability in pronunciation. Therefore, the method used in seventh meeting was learning together combined with role play technique.

The seventh meeting was on Thursday 12, September 2019. The material learnt was expression to ask opinion. The method was learning together followed by role play technique. Audio-visual media through video still used to keep students' interest in learning. In pre-activity, students watched a video which guided them to know some expressions of asking opinion with its response. They could understand it quite well. After that, the lecturer showed them some pictures from some books and magazines to stimulate their argument in responding to the pictures. Although they spoke slowly, but some of them could make 
some examples of the expression by noticing the pictures on the magazines and the books. In this case, pictures could help the students to form the real mental picture on their mind so that they could argue toward its shapes, colors, and material easily. Besides, the colorful pictures stimulated them to think of how the pictures looked like. Wilson as cited in Nurvitasari (2014) in Kosdian (2016:101) state that picture is one of media that used by the teacher to attract students' interest and motivation so that it stimulates students' creativity and thinking. Therefore, it was found that the students also interested to learn through pictures.

After they argued their opinion through some pictures, they worked in group in whilst activity. The goal was the students were able to prepare their own scenario in talking about certain topic and they would argue their opinion related to the topic. In this occasion some magazines and books were used as the reference for them to find the idea for their role play. The interesting part of this meeting was all of them were busy to prepare and to practice their dialogue. Even the students who never talked before seemed to be motivated to speak. Role play gave significant influence toward the students so that they could try to be more confident. Holt and Kysilka (2006) in Krebt (2017:864) state that role play technique is fun and stimulate the students to have student-student communication and also awareness of cooperation among group members. Instead of their slow rate of speaking and pronunciation, they have tried hard to speak. They could make their own examples of the expression of giving opinion.

One good thing noticed from this meeting was the noise which appeared during the performance time. Because all groups were busy to practice their dialogue on their seats, they did not really pay attention to their friends' dialogue. As a result, the students did not really get the idea of what other groups discussed in their role play. Strictly control management should be made to avoid this situation. Nevertheless, the goal to make all students interested to speak was successful. On the other hand, the noise in this meeting should be evaluated so that it would not happen anymore in the next meeting.

The eighth or the last meeting was on Monday 16, September 2019. The material learnt was check if someone understand of something. The method used was team game tournament (TGT). This method used as a solution to avoid disturbance from the noise appeared in the class in the previous meeting. Besides, by having TGT it was hoped that students could work maximally by helping each other, having sense of competition since TGT required students to win a competition in answering the question 
offered in the class, and they could also learn quietly. TGT is a method divides student into five until six members for each group from all level of achievements, different race and gender. TGT maximize students' learning outcome through cooperation and competition. In the tournament, each group can send a representative to answer the questions based on the discussion made with their team. The team win is the team which gets the highest point. Rusman (2011:224) in Rukmana (2017:5) state that the best team or group is the team which can solve the problem together or answering the questions together so that all group members get better understanding and the group can win in the competition. Before giving clear description of how the competition held in the class, the pre-activity will be explained first.

The pre-activity done through video playing. The students analyzed the video by noticing and recognizing the examples of expression explained in the video. Besides, the lecturer also gave oral explanation to make them understood the material easier. Generally, the students could understand that the expression explained in the video was about expression to check if someone understand of something. After that, they worked together in some groups in whilst activity. The tasks have been prepared on some rolled papers. They should identify the example of expression from video, identify the expression from their text book, and make their own examples of expression. A representative of a group was called to take a piece of rolled paper to determine which group would take the first task. After the number of the group known, the representative of that group came in front of the class to take randomly a piece of rolled paper containing the task that should be done. The next thing did was this group tried to finish the task as soon as possible with the time required. If this group could answer correctly, they got point. After that, the group which has just answered the question correctly, take randomly the other rolled paper so that the next group could prepare themselves to answer the questions.

This method made all groups focused to the question which got by a group. Because they wanted to steal the point if that group could not answer the question. Besides, they should be ready to take the next question. The random question given to a group randomly could manage the class to learn quietly. The noise which appeared in the previous meeting could be controlled well. Moreover, the students learnt to think fast and to concentrate to the question they should answer. TGT was fun for the students because learning through game and competition stimulated them to strengthen their cooperation so that they could gain as much point as they could to win the 
competition. In addition, the understanding toward the material could be improved too.

\section{CONCLUSION}

Creating nice and enjoyable learning atmosphere in English as Foreign Language (EFL) context is really significant to enhance students' learning interest. Because learning English is not easy for nonnative students, teachers should concern in choosing the appropriate method and media. Cooperative learning method has been one of effective methods among others to be used in English class as long as it is followed by good preparation related to effective learning instruction, appropriate activities suit to the method and material, and also effective time management in doing the activities.

TAI is a good method to increase students' cooperation among group members and awareness that everyone in group should take responsibility to finish the task. Nevertheless, strictly time allotment management should be done to guide the students finishing their task on time. Meanwhile, learning together model is also effective and comfortable for the students because it has less complicated procedure. The main concern of this model is learning together in a group by helping some learning difficulties of other group members. This model was most used during PDS program at SMP N Abung Selatan.
Moreover, role play technique can be combined with learning together model to motivate inactive and shy students to work in group so that they have confidence and willingness to speak the result of their discussion with their group in front of the class. The last is TGT. TGT is an effective method to make the students focus on the learning and competition held in the class. The noise from the students can be diminished and students can practice to think fast and finish the task before the required time ended.

Meanwhile, the use of media can support the application of the method to gain a better learning result. Audio-visual media can enhance students' interest in learning English because the students feeling enjoyable by seeing the pictures in the video played through the media used. Besides, the media used can give more knowledge for the students about native speakers' pronunciation and it can help them to practice their listening skill too. In short, referring to a lot benefit of using media in the classroom, teachers who still depend on their oral explanation only while delivering the material should try to use media to make learning to be more interesting and decrease students' boredom. In conclusion, effective method and media should be applicated in English class of EFL context so that it can enhance students' learning interest and the 
targeted learning goal can be achieved better.

\section{REFERENCE}

Al Yaseen, W. S. (2014). Cooperative learning in the EFL classroom. The 2014 International Academic Conference Proceedings. Austria.

Almuslimi, F. K. A. (2016). The effect of cooperative learning strategy on English reading skills of 9th grade Yemeni students and their attitude toward the strategy. International Journal of Research in Humanities, Arts, and Literature.

Dzanic, N. D. \& Pejic, A. (2016). The effect of using songs on young learners and their motivation for learning English. An Interdisciplinary Journal, vol.1, (2), 40-54.

Ghaith, G. (2003). Effects of learning together model of cooperative learning on English as a foreign language reading achievement, academic self-esteem, and feeling of school alienation. Bilingual Research Journal, vol.7 (3), 451-474.

Istikhayatun. (2015). The Use of Team Accelerated Instruction Method to Improve Students' Reading Comprehension of Eleventh Grade Students of SMA Muhammadiyah Plus Salatiga in the Academic Year of 2014/2015. Salatiga. A Graduating Paper.

Kosdian, O. (2016). Improving students' speaking skill bby using picture strip story. Indonesian EFL Journal, vol.2, (2), 100-109.

Krebt, D. M. (2017). The effectiveness of role play techniques in teaching speaking for EFL college students. Journal of Language Teaching and Research, vol.8, (5), 863-870.

Kusmaryati, S. E. \& Amertaningrum, I. P. (2017). Exploring students' interest in learning English (a descriptive study in elementary schools in Kudus). The 2nd TEYLIN International Conference April 2017. Kudus.

Ranggen, B. R. (2016). Students' Perception on the Support of English Songs to Students' English Development. Yogyakarta. A thesis.

Rukmana, M. F. A. (2017). The Effectiveness of Using Team Game Tournament (TGT) Technique on Students' Mastery of Simple Present. Cirebon. A Thesis.

Syandri, G. (2015). A case study on the used of visual media in English instructional process at state islamic secondary school 1 Malang. IOSR Journal of Research and Method in Education, vol.4, (4), 46-56.

Thaseem, W. \& Kareema, F. (2017). Implication of multimedia audio-visual aids in the English language classroom. Proceedings of $7^{\text {th }}$ International Symposium, SEUSL 